pain, and vomiting. This type is much less dramatic in its presentation and resolves spontaneously. Unless a radiograph taken during an attack shows jejunum lying within the stomach the diagnosis can never confidently be made. This was however achieved in the cases reported by Chamberlin (1940) and Sibley (1944) and in both instances the intussusception had reduced itself by the time laparotomy was undertaken. In the present case the two previous attacks and the readiness with which the intussusception could be reduced and reproduced at operation lead one to suppose that it was an 'acute on chronic' intussusception and the absence of vomiting was due to the fact that the condition had not long been present.
Urgent operation is imperative as soon as the patient has been made fit to withstand it. Resection of a gangrenous intussusceptum may be required but apart from this all that is necessary is reduction of the intussusception. Recurrence is a matter of the very greatest rarity and in two reported cases (Burdman, 1954; Douglas, 1954) recurrence had taken place despite measures that were taken on the first occasion to prevent it. The greatest service that the surgeon can render to his patient is to recognise the condition at the outset and not to prolong the operation by trying to prevent what will probably never happen again.

My thanks are due to Mr. Norman Tanner for permission to report this case.

\title{
REFERENCES
}

Burdman, M. (1954): Report of a Thrice-recurring Retrograde Intussusception of the Efferent Loop of Jejunum Through a Gastroenterostomy Stoma with a Theory as to the Ætiology, Postgrad. med. Y., 30, 200.

Chamberlin, G. W. (1940): Chronic Recurrent Jejunogastric Intussusception Through a Gastroenterostomy Stoma, Amer. Y. Surg., 49, 510.

Douglas, W. K. (1954): Recurrent Retrograde Gastrojejunal Intussusception, Postgrad. med. Ұ., 30, 204.

McNamara, W. L. (1944): Retrograde Jejunogastric Intussusception Through a Subtotal Gastrectomy Stoma, Ann. Surg., 120, 207.

MoRonEY, J. (1948): Some Interesting Gastrojejunal Lesions, Brit. F. Surg., 35, 374.

Poliquin, P. A. (1944): L'Invagination Jejunogastrique, Un. méd. Can., 73, I8.

Sibley, W. L. (1934): Chronic Intermittent Intussusception Through the Stoma of a Previous Gastroenterostomy, Proc. Mayo Clin., 9, 364 .

\section{A CASE OF APLASTIC ANAEMIA TREATED BY ISOLOGOUS BONE MARROW INFUSION}

\author{
D. E. PegG, M.D. \\ Lecturer in Hamatology, Westminster Hospital, \\ London, S.W.I
}

\author{
W. J. D. Fleming, M.B., B.Chir. \\ Senior Lecturer in Hamatology, Royal Free Hospital, \\ London, W.C.I
}

Nigel Compston, M.A., M.D., F.R.C.P.

Physician, Royal Free Hospital, London, W.C.I

JACOBSON and his colleagues have shown in a series of most elegant experiments that shielding part of the haemopoietic tissue during irradiation, or the post-irradiation implantation of healthy isologous haemopoietic tissue will restore the bone marrow cellularity of irradiated animals (Jacobson and Simmons, 1948; Jacobson, Marks, Gaston, Robson and Zirkle, I949; Jacobson, Marks, Robson, Gaston and Zirkle, 1949; and Jacobson, Simmons, Marks, Robson, Bethard and Gaston, 1950). These observations were extended by Lorenz and his co-workers, when it was demonstrated that the intravenous infusion of viable isologous marrow cells prevented the death of lethally irradiated mice and guinea pigs (Lorenz, Uphoff, Reid and Shelton, I95I). Attempts to use homologous instead of isologous marrow soon revealed difficulties and dangers inherent in the transfer of cells between genetically distinct animals; the homologous marrow proved to be less effective (Lorenz, Congdon and Uphoff, I952) and it frequently produced secondary disease (Barnes and Loutit, 1954; Mathé, Bernard, deVries, Schwarzenberg, Larrieu, Lalanne, Dutreix, Amiel and Surmont, 1960). It is not surprising, therefore, that when marrow infusion techniques come to be applied in clinical medicine, great interest should be given to those circumstances where the experimental isologous situation can be duplicated in man, that is, where an identical twin can be used as the marrow donor. In addition, it was a logical extension of the radiation protection work to attempt to treat the bone marrow aplasia of disease states by isologous marrow 


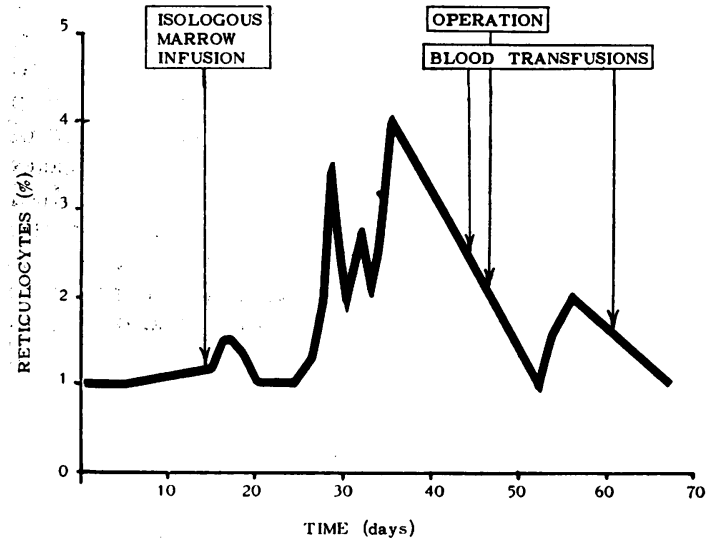

FIG. I.-Reticulocyte counts following isologous marrow infusion.

infusions. Obviously, such situations are very rare, but no less than ten isologous marrow infusions have been reported; 7 were patients suffering from leukaemia (Atkinson and Mahoney, 1958; Atkinson, Mahoney, Schwartz and Hesch, 1959; Atkinson, 1960; Aleksandrowicz and Blecharski, 1960); I was a patient with disseminated seminoma (Kurnick, 1962) and 2 were cases of aplastic anaemia (Trentin, 1960; Robins and Noyes, 196I). In this paper we describe a third case of aplastic anaemia treated by an isologous marrow infusion.

\section{Case Report}

The patient, a 54-year old male, was admitted to the Royal Free Hospital with a two-year history of progressive lassitude and weakness; more recently he developed increasing pallor and had been confined to bed for the last two months. The patient had been treated by a Christian Science practitioner until one week before admission when a general medical practitioner was called in; he administered $750 \mu \mathrm{g}$. Vitamin $B_{12}$. There was no history of any other medication.

On examination the patient was found to be semiconscious and on the verge of cardiac decompensation with marked air hunger; the jugular venous pressure was raised and there was moderate liver enlargement with marked liver tenderness, but no odema. The blood pressure was $100 / 50 \mathrm{~mm} \mathrm{Hg}$. The patient was obviously grossly anæmic, but there was no neurological dysfunction. The hæmoglobin level was $1.5 \mathrm{~g} . / 100 \mathrm{ml}$. (10\%), and the reticulocyte count was $2 \%$, which gave an absolute count of $7,500 / \mathrm{cu} . \mathrm{mm}$. Cline and Berlin (1963) have shown that a reticulocyte level of $40,000 /$ cu.mm. forms a satisfactory division between normal and subnormal erythropoiesis, and consequently this patient's erythroid activity was very much reduced. The leucocyte count was $15,300 / \mathrm{cu} . \mathrm{mm}$. with a normal differential. A sternal bone marrow aspiration produced fatty marrow particles containing relatively few marrow cells and a notable paucity of erythrocyte precursors. There was evidence of rapid discharge of myeloid cells and megakaryocytes were numerous with normal thrombopoiesis. The patient was also found to be suffering from prostatic hypertrophy with retention of urine. The blood urea was $45 \mathrm{mg}$./ $/ 100 \mathrm{ml}$. A provisional diagnosis of aplastic anæmia, possibly of the pure red cell aplasia type was made. During the first

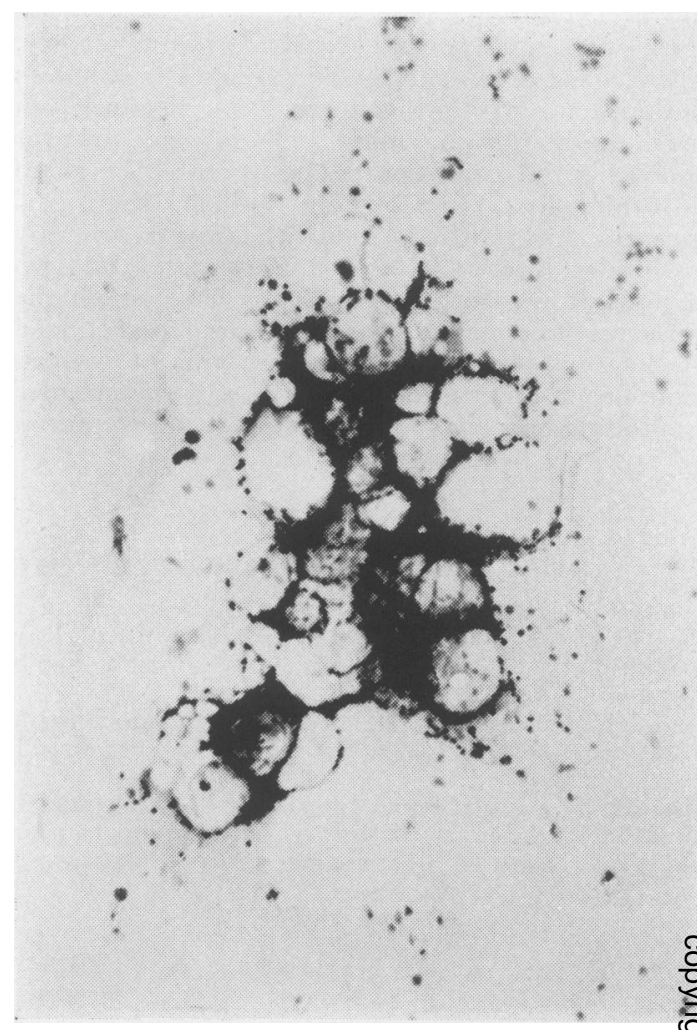

Fig. 2.- Smear of bone marrow cells aspirated (a) before and (b) three weeks after isologous bone marrow infusion (May-Grunwald-Giemsa stain).

three days transfusions of packed red cells from r.6 l. of $\overrightarrow{\vec{A}}$ blood were given, and this raised the hæmoglobin levelo to $6.1 \mathrm{~g} . / 100 \mathrm{ml}$. $(42 \%)$. During the second week a radio-active iron study revealed a plasma clearance half-time of 315 minutes (normal $=70-140 \mathrm{mins}$.) and the surface counting pattern fully confirmed the diagnosis -0 of red cell aplasia. There was no radiological evidence of 3 a thymoma. Treatment was instituted with Vitamins and $B_{12}$, pyridoxine and methyl testosterone, but after two months no evidence of response was observed. Further blood transfusions amounting to a total of 3.2 1. 응 raised the hæmoglobin level to $11.4 \mathrm{~g} . / 100 \mathrm{ml}$. $(78 \%)$.

The patient was known to have a twin brother; theiro appearance was similar and it was known that as children they were indistinguishable. Details of placental anatomy were not available and the presence of large을 numbers of transfused erythocytes in the patient's circulation rendered proof of identity by means of blood $\mathrm{N}$ group antigen studies impossible; however, blood typing $N$ was carried out by Dr. A. E. Mourant, and the results? did not eliminate the possibility of identity. In view of $\omega$ the severe nature of the patient's illness, it was decidedo to accept the evidence favouring identity and proceed with an isologous marrow infusion without furthere delay.

Bone marrow was collected from the healthy twin by? aspiration from the sternum and pelvis using the 0 technique already described (Pegg and Kemp, 1960). $\bar{o}$ The infusion was given by the intravenous route $\mathbb{D}$ immediately after centrifugal separation of the fat $?$ supernatant fluid. The total number of nucleated cells $\stackrel{\unrhd}{\varrho}$ 


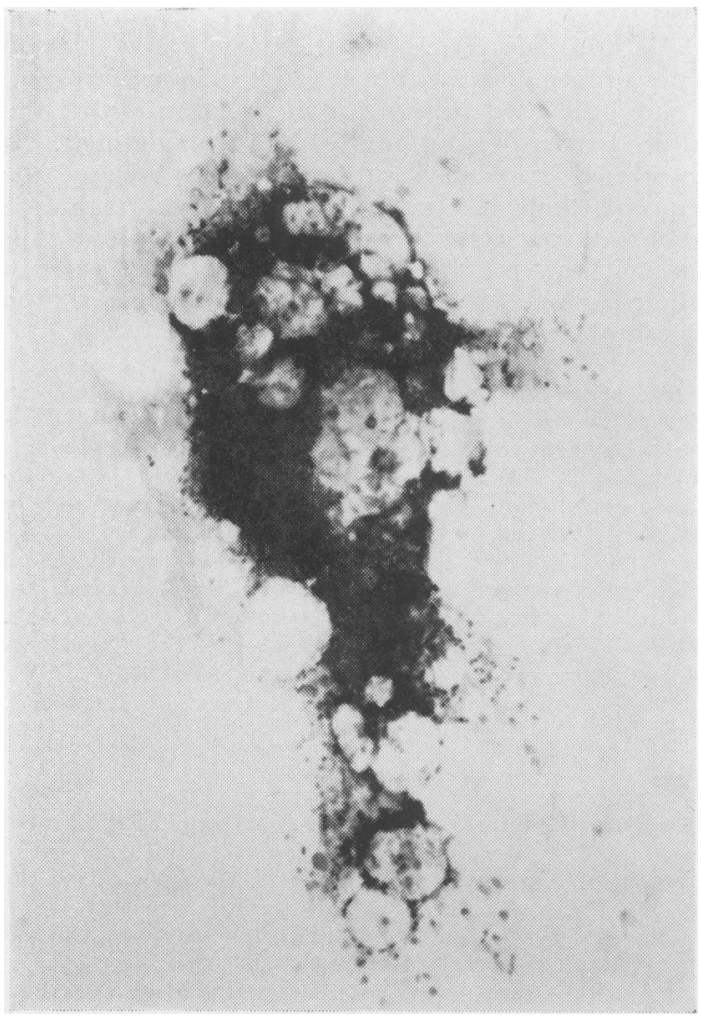

FiG. 2 (b). was unchanged for 10 days and then a rise in the reticulocyte count occurred, reaching $4 \%(120,000)$ cu.mm.) on the 22 nd day (Fig. I). Since all the reticulocyte counts were derived from a scan of $I, 000$ consecutive red cells, this increase is significant at the $5 \%$ level. At this time a sternal marrow aspiration produced many particles with an increase in activity spread throughout the cell types and notably including a marked increase in erythropoietic activity (Fig. 2). However, further radioactive iron studies failed to demonstrate any improvement. At this time the patient was well enough to tolerate the prostatectomy, which was carried out by Mr. J. P. Hopewell. 0.81 . of blood were transfused three days before and a further 1.2 l. during the operation. Four days after the operation the reticulocyte count was found to have fallen to $1.0 \%$, but within four more days it had risen to $2.1 \%$. The patient was discharged home 7 weeks after the marrow infusion and since then has been studied for rather more than a year. His blood transfusion requirements during this period have amounted to I 1.6 litres; transfusions every 6-8 weeks have kept his hæmoglobin level in the range of 8-12 g. $/ 100 \mathrm{ml} .(55-82 \%)$ (Fig. 3).

\section{Discussion}

The patient showed a considerable reticulocyte response following the marrow infusion and this occurred at roughly the expected time. However, the reticulocyte count then fell following a large blood transfusion, and although there was a second reticulocytosis, this too fell after a further blood transfusion. The bone marrow cellularity was improved three weeks after the infusion, but did not return to normal, and during the subsequent year the patient's blood transfusion requirements were considerable. We conclude that although

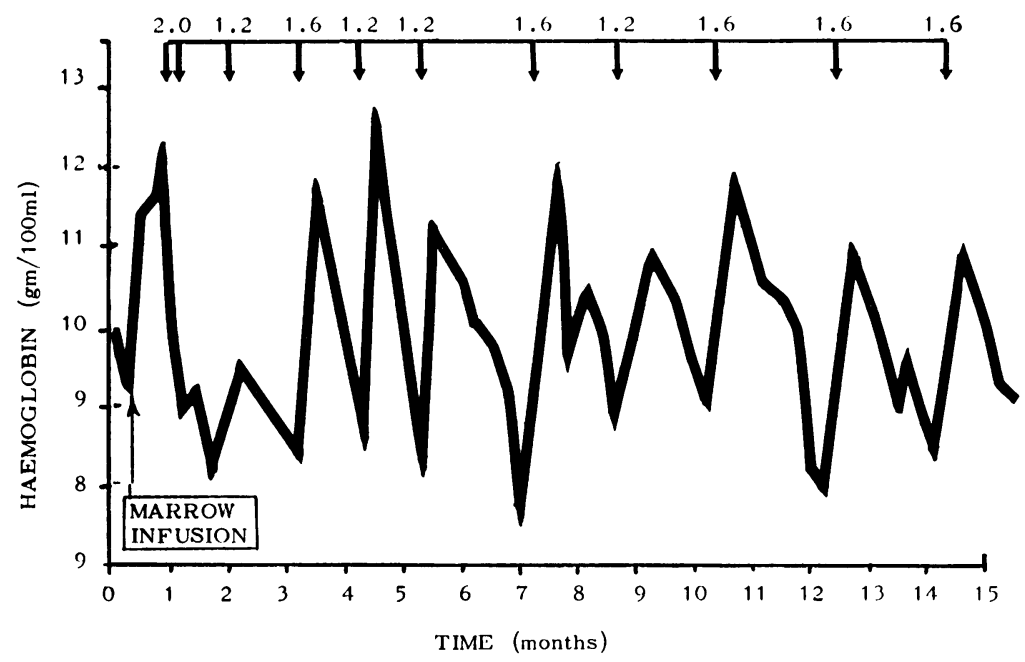

FIG. 3.-Hamoglobin levels following isologous marrow infusion.

obtained was $8.1 \times 10^{9}$, with an estimated $4.8 \times 10^{9}$ marrow cells. This provided an infusion of $71 \times 10^{6}$ marrow cells $/ \mathrm{kg}$., which, on the basis of animal experiments, should be adequate for isologous infusion in man (Pegg, 1962).

Following the marrow infusion the patient's condition the initial effect on the reticulocyte count strongly supports the contention that the infusion had some effect, it is equally clear from the longterm result that the procedure was not curative.

The two previously published cases of aplastic 
anaemia treated by isologous bone marrow infusions differed in that both were children and the disease was probably drug-induced. The first case, briefly reported by Trentin, failed to respond significantly to two marrow infusions, but Robins and Noyes' case showed a gradual improvement in the reticulocyte count followed by a return to normal. Although this case appears to be quite impressive, the variability of the natural history of this form of aplastic anaemia makes interpretation very difficult. In Trentin's case it seems that there was an abnormality in the 'marrow environment' rather than in the actual bone marrow cells, and there is even more striking evidence favouring such an interpretation in our case. The infused marrow proliferated initially, but for some reason failed to establish itself. The possibility of splenic or thymic inhibition must be considered; in this case there is no suggestive evidence, but it looks as if some environmental abnormality is the primary cause of the disease.

\section{Summary and Conclusions}

An adult case of aplastic anaemia was treatễ with an isologous (identical twin) marrow infusio There was evidence of initial proliferation of the infused marrow, but this was not maintained. It is argued that such an occurrence favours the concept that the environment rather than tlite bone marrow cells themselves are at fault in this case. However, the marrow infusion was withow side effects and would probably be worth repeatir? in similar circumstances.

We are most grateful to the British Empire Cancê? Campaign for financial assistance, including a full-tin research grant to one of us (D.E.P.) We would also like to thank Dr. D. S. Murray for many of the follow-yg blood counts, and Dr. P. Hansell of the Department of Medical Illustration, Westminister Medical School, for preparing Figures $I$ and 3 , and the Department Medical Photography, The Royal Free Hospital, f Figure 2. This paper contains material included in Thesis accepted for the M.D. degree of the University of London.

\section{REFERENCES}

Aleksandrowicz, J., and Blecharski, J. ( 1960): Leukæmia in Two Pairs of Monozygous Twins: Attempts at Treatment

by Bone Marrow Transfusion, Sang, 31, 49.
Atkinson, J. B. (1960): Summary of Proceedings of the Conference on Transplantation of Bone Marrow, Blood, 1要,

I508. Transplantation. 7th Congress of the International Society of Hæmatology, September 7-13, 1958.

- , Schwartz, I. R., and Hesch, J. (1959): Therapy of Acute Leukæmia by Total Body Radiation and Marrow Transplantation from an Identical Normal Twin, Blood, 14, 228.

BARNES, D. W. H., and Loutit, J. F. (1954): Spleen Protection: The Cellular Hypothesis. Radiobiology Sympos: Ed. Bacq, Z. M., and Alexander, P. (1955): p.134. London: Butterworth.

Cline, M. J., and Berlin, N. L. (1963): The Reticulocyte Count as an Indicator of the Rate of Erythropoiesis, Amean F. clin. Path., 39, 121.

Jacobson, L. O., Marks, E. K., Gaston, E. O., Robson, M., and Zirkle, R. E. (1949): The Role of the Spleen $\mathbb{\Omega}$ Radiation Injury, Proc. Soc. exp. Biol.,; (N.Y.), 70, 740. Med., 34, 1538 . , (1949): Effect of Spleen Protection on Mortality Following X-irradiation, f. Lab. cli

_ , and Simmons, E. L. (1948): The Effect of Splenectomy on Radiostrontium Toxicity, Anat. Rec., roo, 678. F F

—, MArks, E. K., Robson, M. J., Bethard, W. F., and Gaston, E. O. (1950): The Role of the Spleen 通 Radiation Injury and Recovery, f. Lab. clin. Med., 35, 746.

KurNick, N. B. (1962): Autologous and Isologous Bone Marrow Storage and Infusion in the Treatment of Myel Suppression, Transfusion, 2, 178.

LORENZ, E., CongDon, C. C., and UPHOFF, D. (1952): Modification of Acute Irradiation Injury in Mice and Guine Pigs by Bone Marrow Injections, Radiology, 58, 863 .

- UPHOFF, D., REID, T. R., and Shelton, E. (I95I): Modification of Irradiation Injury in Mice and Guinea Pig by Bone Marrow Injections, F. Nat. Cancer Inst., 12, 197.

Mathé, G., Bernard, J., deVries, M. J., Schwarzenberg, L., Larrieu, M. J., Lalanne, C. M., Dutreix, Aoj Amiel, J. L., and Surmont, J. (1960): Nouveaux Essais de Greffe de Moelle Osseuse Homologue Après I $\mathrm{I}^{2}$ radiation Totale Chez des Enfants Atteints de Leucemie Aigue en Remission, Rev. Hemat., 15, I 15.

PEGG, D. E. (1962): A Quantitative Study of Bone Barrow Grafting: Implications for Human Bone Marrow Infusio Brit. F. Cancer, 16, 400.

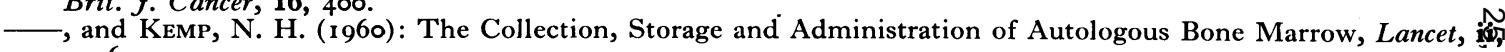

I426.
Robins, M. M., and Noyes, W. D. (1961): Aplastic Anæmia Treated with Bone Marrow Transfusion from Identical Twin, New Engl. F. Med., 265, 974 .

Thomas, E. D., Lochte, H. L., Cannon, J. H., Sahler, O. D., and Ferrebee, J. W. (1959): Supralethal Whole Bod̦ Irradiation and Isologous Marrow Transplantation in Man, $\mathcal{F}$. Clin. Invest., 38, 1709.

$\longrightarrow,-$ and SAHLER, O. D. (1959): Treatment of Acute Leukæmia by Supralethal Whole Body Irradiation and Isologous Marrow Transplantation, Ibid., 38, 1048.

Trentin, J. J. (1960): Summary of Proceedings of Conference on Transplantation of Bone Marrow, Blood, 16, 1508. 